\section{Conservation priorities and potential threats influencing the hyper-diverse amphibians of Madagascar}

\author{
FRANCO ANDREONE \\ Museo Regionale di Scienze Naturali, \\ Via G. Giolitti, 36, I-10123 Torino (Italy) \\ E-mail: f.andreone@libero.it \\ LUCA MARIA LUISELLI \\ FIZV, Herpetological Section, \\ Via dei Cochi, 48/B, I-00133 Roma (Italy) \\ E-mail: hucamlu@tin.it
}

\section{ABSTRACT}

The conservation of Madagascan amphibians was assessed using a set of natural history parameters. The more than two hundred species were grouped into 51 operational conservation units to get more reliable results than those afforded by the low level of knowledge available for most of the species. Results in terms of ecological sensitivity were obtained by means of a univariate ranking and cluster analysis. Mantelline mantellids and cophyline microhylids were among the amphibians most sensitive, since they are closely related to a stable rainforest environment. The less sensitive species in terms of ecological preferences appeared to be those breeding in temporary ponds and living in dry-arid and savannah-like areas (e.g., Dyscophinae, Laliostoma labrosum, and Hyperoliidae). Other species, closely linked to the aquatic environment, are less affected by deforestation, and may occur in already degraded areas when a stream network and associated gallery forest still exist. For some genera (e.g., Mantella and Scaphiophryne) the pet trade may constitute a threat (when dealing with already disturbed and restricted populations). In this sense, most Mantella species must be managed in terms of number of specimens exported. This is especially true for $M$. cowani and $M$. bernbardi, which have a very narrow distribution area. Mantella cowani is severely endangered, since it is a "plateau" species, and suffers from a combination of both habitat degradation and capture for commerce. A principal component analysis on Ranidae, Boophinae, Mantellinae, Laliostominae, Dyscophinae, Scaphiophryninae, Cophylinae, and Hyperoliidae showed that the variables ordering the various taxa were activity type, distribution, and habitat breadth.

KEY WORDS: Amphibians - Categorisation - Conservation - Ecology - Madagascar - Threats.

\section{ACKNOWLEDGEMENTS}

For the exchange of information and technical support we thank many people: G. Aprea, C. Avesani, J. L. Behler, O. Behra, Q. Bloxam, L. Brady, J. E. Cadle, A. Dubois, J.-M. Garreau, F. Glaw, S. M. Goodman, D. Halleux, M. Hatchwell, R. Jesu, G. Kuchling O. Langrand, J. McKinnon, F. Mattioli, R. Nincheri, R. A. Nussbaum, A. Ohler, J.-P. Paddack, H. Rabetaliana, T. Rahagalala, G. Rakotoarisoa, D. Rakotomalala, E. Rakotomavo, J.-B. Ramanamanjato, F. Rakotondraparany, D. Rakotondravony, L. Ramarojaona, H. Randriamahazo, H. Randrianasolo, J. E. Randrianirina, A. P. Raselimanana, C. J. Raxworthy, R. Razafindrasoa, Y. Rumpler,

(Received 28 February 2002 - Accepted 5 June 2002)
G. Schimmenti, M. O. Sohantenaina, M. Staniszewski, D. Vallan, and $M$. Vences. F. Glaw and D. Vallan also made useful comments on an early draft of this paper. The field work was made possible due to the agreement of MEF and ANGAP, which delivered the necessary authorisations. Two referees accurately reviewed the manuscript. Last but not least, thanks to N. E. Baldaccini for his editorial assistance and useful advice.

\section{INTRODUCTION}

The work by Myers et al. (2000) highlighted the fact that Madagascar is among the world's "hottest biodiversity hotspots", featuring a large number of endemic species. Apart from the well known' and appealing lemurs, Madagascar is characterised by a rich herpetofauna, which has intriguing biogeographic relationships with the faunae of Africa, Asia and South America. It is also very interesting that many supraspecific amphibian and reptile groups are endemic of the "Grand'île", and belong to single clades (Vences \& Glaw, 2001a). This is the case, for example, with Malagasy boas (Vences et al., 2001), iguanas (Opluridae) (Blanc et al., 1983), and some ranoid anurans, which were included within the family Ranidae (with three subfamilies: Raninae, Mantellinae, Rhacophorinae), but that are now considered as belonging to a single Malagasy clade (Mantellidae) (Vences \& Glaw, 2001a). All this witnesses the largely independent biogeographic history of Madagascar, which separated from continental Africa about 165 millions years ago (Raxworthy et al., 2002).

The high endemicity level is especially apparent for the hyper-diverse amphibian fauna, which is also peculiar in terms of taxonomy and phylogeny. In fact, a considerable amount of new species was discovered after recent inventory works. The number of 182 species (as given by Glaw \& Vences, 2000) has been rapidly surpassed, and that of 209 in the present work is only indicative, since many more species await description. Despite this species richness, little information is so far available on the biology and conservation of most Malagasy frogs. The few contributions on this matter are often so generic (Tonge, 1991; Andreone, 1994; Raxworthy \& Nussbaum, 2000), that considerations are sometimes anecdotal, or mainly given in a qualitative way for pet-traded species (e.g., those of the genus Mantella). Moreover, it is evident that most of Malagasy amphibians are closely related to forest habitats, and that the rapid vanishing of these ecosystems (Ganzhorn et al., 2001) will be followed by the rarefaction of many species. Since less than $11 \%$ of the island is now forested (Benstead et al., 2000), it is also likely that many unknown frog species already became extinct following the human colonization, around 2000 years ago.

It is claimed that amphibians are declining all around the world (Blaustein \& Wake, 1990): the reasons for this were not fully ascertained, although it is likely that their double life, permeable skin, general vulnerability to external factors, and top predator position make them ex- 
tremely sensitive. Anyhow, despite a certain knowledge of their situation e.g. in Latin America (Heyer et al., 1988; Young et al., 2001), and Australia (Hero \& Gillespie, 1997), little is known of their rarefaction and decline in the tropics; amphibians are also good subjects for zoological inventories, since they are easily surveyed and are closely linked to their environment (Andreone \& Randrianirina, 2000). It is worth stressing that they are also frequently captured for export, with some species - at least locally - being threatened by the export rate (Behra \& Raxworthy, 1991): high numbers of Mantella, Scapbiophryne and Dyscophus are quite regularly captured, although occasionally also other species may be traded on (Jenkins \& Rakotomanampison, 1994). Due to the high capture and exportation rate and apparently narrow distribution, the "tomato frog" Dyscophus antongili was included in CITES Appendix I, while all the Mantella species are now in Appendix II.

It was thus decided to carry out an analysis of the amphibian fauna of Madagascar, in order to obtain reliable information addressed to conservation. The goals of this paper are (1) to establish which of the amphibians of Madagascar share general traits of habitat preferences, so as to identify ecologically similar groups, (2) to investigate how these traits and the group assessment are important in a general conservation assessment; (3) to estimate which species (or groups of species) are particularly threatened at present; (4) to provide basic indications on the main conservation priorities.

\section{MATERIALS AND METHODS}

\section{An overview of the Madagascan amphibians}

Madagascan amphibians are included in four anuran families: Mantellidae, Microhylidae, Ranidae, and Hyperoliidae (Vences \& Glaw, 2001a). Mantellids are a Madagascan monophyletic group, represented by three subfamilies (Mantellinae, Laliostominae, and Boophinae), which were formerly considered either distinct families, or ranid or rhacophorid subfamilies (e.g., Duellman \& Trueb, 1986; Blommers-Schlösser \& Blanc, 1991; Andreone, 1993; Blommers-Schlösser, 1993; Glaw \& Vences, 1994). Mantellines include two genera, Mantidactylus and Mantella, which show peculiar features related to reproduction, among which cephalic amplexus, absence of nuptial pads, and presence (in most species) of femoral glands. The heterogeneous genus Mantidactylus is now split into 12 subgenera (Andreone, in press b), and it is likely paraphyletic (Vences et al., 2002d). The genus Mantella features 16 species (Vences et al., 1999; Odierna et al., 2001; Staniszewski, 2001), with aposematic colouration and accumulation of alkaloids in the skin (Daly, 1984). The genus Aglyptodactylus, formerly included in Rhacophorinae or in Raninae (e.g., Glaw \& Vences, 1994; Glaw et al., 1998), now belongs to Laliostominae together with Laliostoma labrosum (formerly Tomopterna labrosa) (Vences et al., 2000a; Vences \& Glaw, 2001a). Boophines include tree-frogs of the genus Boophis, which lay eggs in streams or still water after a typical amplexus (Vences et al., 2002a). Ranids are the only non-autochthonous amphibians in Madagascar, and include the widely distributed Ptychadena mascareniensis (present also in the Mascarene Islands and in continental Africa), and Hoplobatracbus tigerinus, which was introduced in Madagascar from SE Asia. Microhylids are represented by ten genera (Glaw \& Vences, 1994, 1997a, b) in three subfamilies:
Dyscophinae (Dyscopbus), Scaphiophryninae (Paradoxopbyla and Scaphiopbryne), and Cophylinae (Cophyla, Platypelis, Anodonthyla, Plethodontobyla, Madecassophryne, Rhombophryne, and Stumpffia). Finally, the Malagasy hyperoliids are represented by a single endemic genus (Heterixalus), which includes arboreal species, rather adapted to live in savannah-like areas, and related to the African Hyperolius and Tachycnemis from the Seychelles (Vences et al., 2000b).

\section{Nomenclature and group definition}

The nomenclature adopted in this paper is based upon that of Glaw \& Vences' (1994) field-guide. Since then many new species have been described: beside the species reported in the fieldguide, we also included the species described (or revalidated) in the meanwhile (Andreone et al., 1995, 1998, 2001, 2002; Cadle, 1995; Andreone, 1996; Glaw \& Vences, 1997a, b, c, 1999, 2002; Glaw et al., 1998, 2000, 2001; Vallan, 2000a; Vences \& Glaw, 2002; Vences et al., 2000a, b), and others which are in description (Andreone et al., 2002, in press; Glaw \& Vences, in press; Vences \& Glaw, 2001b; Vences et al., 2002b, in press a, b).

One major problem is the high number of Malagasy amphibians, the total of those considered being 209 (in June 2002), including the exotic Hoplobatrachus tigerinus (non treated in the analysis). We are aware that this list will soon become "old" and new species will be added. Moreover, many were recorded only at their type locality and virtually nothing is known of their life preferences, a condition in common with other tropical amphibians (Rödel, 2000). Since it was impossible to obtain a reliable categorisation for each species, several taxa were pooled in a few major categories and considered for the general analysis. When possible existing categories, like the Mantidactylus subgenera or Boophis and Mantella groups (Glaw \& Vences, 1994; Vences et al., 1999) were utilised. In other cases, we used new assemblages (e.g., the Heterixalus groups, which are based upon unpublished biomolecular information by $M$. Vences and $F$. Glaw). The categories used should be regarded as "operational conservation units" (OCUs). When one or more taxa were clearly different in terms of ecology or biogeography from other taxa of the group, they were split and treated separately. This was the case, for example, of three species of the Boophis tephraeomystax-group ( $B$. doulioti, B. xerophilus, $B$. tepbraeomystax), of one species of the subgenus Mantidactylus (M. microtympanum), which was separated from $M$. grandidieri and $M$. guttulatus and associated to $M$. microtis (Andreone, in press; F. Andreone and R. A. Nussbaum, unpublished), and of $M$. guibei and $M$. bertini, which were considered separately from the remaining species of Blommersia. When new groups were used, they were given an "unofficial" name (e.g. Heterixalus group 1, group, 2 , etc.). In other cases a group name was split in two [e.g., Boophis tephraeomystax group (partim 1), Boophis tephraeomystax (partim 2)]. Although some of these "new" groups likely have taxonomic validity, we did not want to cause problems in a paper without taxonomic finalities. These are therefore "working names" without any nomenclatorial validity. A detailed list of the analysed OCUs and abbreviations used is given in Tables I, II.

\section{Analysed parameters}

As in previous studies (Andreone \& Luiselli, 2000), a set of variables among those which affect the survival of amphibian populations was used to characterise each species. These variables were classified into categories ranging from 0 (least risk) to 3 (highest risk). The categories were based on published average conditions, personal information, or Authors' own experience (Tables I, II). The rationale for these parameters is commented on below.

1. Environmental adaptability (EA): $0=$ adaptable species, found even in or around small villages; 1 = relatively adaptable species (found in small natural fields); 2 = species with scarce adaptability (found in average sized natural forests); 3 = species without any adaptability, and found only in wide patches of well preserved natural habitats. 
TABLE I - Operational conservation units $(O C U)$ and abbreviations of Malagasy ampbibians belonging to Mantellidae.

Abbreviation OCU

MANTELLIDAE - BOOPHINAE (BOO)

1 BMI

2 BOG

$3 \mathrm{BOA}$

4 BOI

5 BOL

$6 \mathrm{BOM}$

$7 \mathrm{BOO}$

8 BOR

9 BOT

10 AMA

11 ALA

12 LAL

13 BLO

14 BRY

$15 \mathrm{CHO}$

16 GUI

17 HYL

18 LAU

19 MAN

20 MAS

21 MBG

$22 \mathrm{MBO}$

23 MGR

24 MMI

25 MPS

$26 \mathrm{OCH}$

27 PAN

28 SPI

29 MAA

30 MAB

31 MAC

32 MAV

33 MAL

34 MAM

35 MBE

\section{Boophis microtympanum group}

Boopbis goudoti group

Boopbis albilabris group (partim 1)

Boophis tephraeomystax group (partim 1)

Boopbis luteus group

Boopbis majori group

Boopbis albilabris group (partim 2)

Boophis rappiodes group

Boopbis tephraeomystax group (partim 2)

MANTELLIDAE - LALIOSTOMINAE (LAL)

Aglyptodactylus group 1

Aglyptodactylus group 2

Laliostoma labrosum

MANTELLIDAE - MANTELLINAE (MAN)

Mantidactylus (Blommersia) (partim 1)

Mantidactylus (Brygoomantis)

Mantidactylus (Cbonomantis)

Mantidactylus (Guibemantis)

Mantidactylus (Hylobatrachus)

Mantidactylus (Laurentomantis)

Mantidactylus (Mantidactylus) (partim 1)

Mantidactylus (Gepbyromantis),

[Mantidactylus asper group]

Mantidactylus (Blommersia) (partim 2)

Mantidactylus (Gephyromantis),

[M. boulengeri group]

Mantidactylus (Pbylacomantis),

[Mantidactylus granulatus group]

Mantidactylus (Mantidactylus) (partim 2)

Mantidactylus (Phylacomantis),

[Mantidactylus pseudoasper group]

Mantidactylus (Ocbtbomantis)

Mantidactylus (Pandanusicola)

Mantidactylus (Spinomantis)

Mantella aurantiaca group

Mantella bernbardi group

Mantella cowani group

Mantella betsileo group (partim 2)

Mantella laevigata group

Mantella madagascariensis group

Mantella betsileo group (partim 1)
Species

laurenti, microtympanum, williamsi

boebmei, brachychir, burgeri, goudoti, madagascariensis,

periegetes, reticulatus, rbodoscelis, rufioculis

albilabris

guibei, billenii, idae, lichenoides, opistbodon, pauliani albipunctatus,

andobabela, andreonei, anjanabaribeensis, ankaratra, elenae,

englaenderi, jaegeri, luteus, septentrionalis, sibilans

blommersae, feonnyala, baematopus, majori, marojezensis,

miniatus, picturatus, pyrrbus, vittatus

occidentalis

erythrodactylus, mandraka, rappiodes, viridis

tephraeomystax, doulioti, xerophilus

madagascariensis
securifer, laticeps
labrosum

argenteus, blommersae, domerguei, grandisonae, kely, sarotra, wittei alutus, ambobimitombi, betsileanus, biporus, curtus,

madecassus, pauliani, tricinctus, ulcerosus

aerumnalis, albofrenatus, brevipalmatus, opiparis

melanopleura, opiparis opiparis, sp. 1, sp. 2

depressiceps, elegans, kathrinae, liber, tornieri

lugubris

borridus, malagasius, striatus, ventrimaculatus

grandidieri, guttulatus

ambobitra, asper, luteus, plicifer, sculpturatus, spinifer

bertini, guibei

blanci, boulengeri, decaryi, eiselti, klemmeri, leucocephalus,

rivicola, silvanus, schilfi, thelenae, webbi

cornutus, granulatus, leucomaculatus, redimitus, tandroka,

tschenki, sp. 3, sp. 4

microtis, microtympanum

corvus, pseudoasper

ambreensis, femoralis, majori, mocquardi

flavobrunneus, pulcher, punctatus, albolineatus, bicalcaratus

aglavei, brunae, fimbriatus, massi, peraccae, phantasticus

aurantiaca, crocea, milotympanum

bernbardi

baroni, cowani, baraldmeieri, nigricans

expectata, manery, viridis, sp. 1

laevigata

madagascariensis, pulchra

betsileo

Mantidactylus sp. 1 and sp. 2 will be described by Vences \& Glaw (in press a); Mantidactylus sp. 3 by Andreone et al. (in press); Mantidactylus sp. 4 by Vences et al. (2002b); Mantidactylus opiparis opiparis and M. a. melanopleura will be recognized as distinct species by Vences \& Glaw (in press a); Mantella sp. 1 is a still undescribed species.

2. Habitat breadth (HB): $0=$ species living within $5 \mathrm{~m}$ from water bodies (aquatic and semi-aquatic species); $1=$ species living within $20 \mathrm{~m}$ from water bodies (riverine species); 2 = species living $>20 \mathrm{~m}$ from water bodies (forest species); 3 = species living within phytotelmata (e.g., bamboo holes and leaf axils) (phytotelmous species). Amphibians which are closely linked to stream habitats benefit from a more stable environment: the presence of water warrants the persistence of considerable atmospheric and ground humidity and the reproduction of most amphibians.

3. Arboreality (A): $0=$ aquatic or semi-aquatic species; $1=$ semi-arboreal species (species living on shrub-like vegetation; $2=$ arboreal species (inhabiting trees, usually above $2 \mathrm{~m}$ ); $3=$ terrestrial 
TABLE II - Operational conservation units (OCU) and abbreviations of Malagasy amphibians belonging to Ranidae, Hyperoliidae, and Microbylidae.

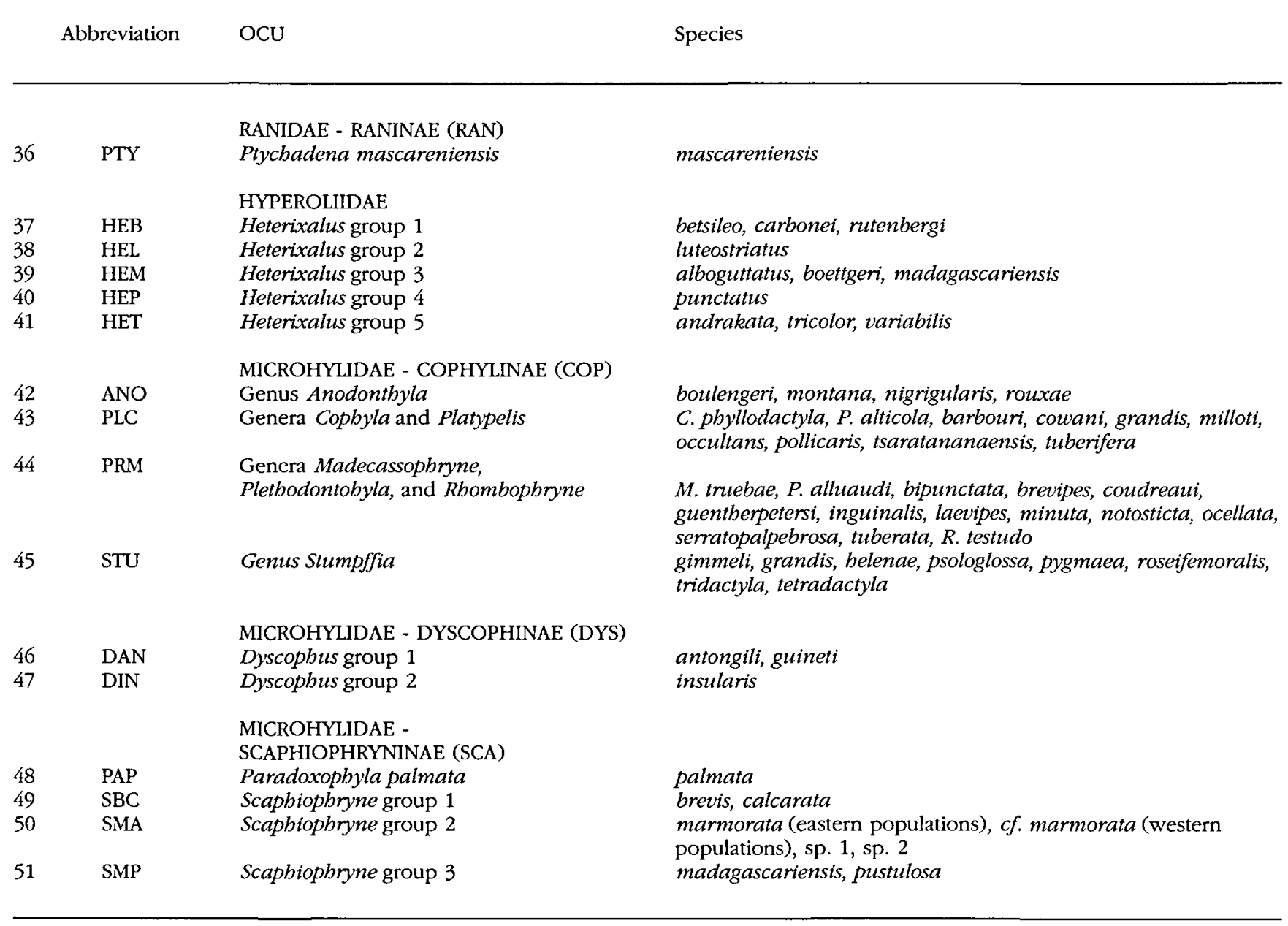

Scaphiophryne sp. 1 and sp. 2 will be formally named by Vences et al. (in press b).

species. Terrestrial amphibians are in general more sensitive than the arboreal ones, depending on the existence of a stable forest layer substrate, which disappears (or is altered) when deforestation occurs (Andreone, 1994; Pough et al., 1998; Lemckert, 1999).

4. Reproductive mode and egg type (RM): $0=$ species breeding in stagnant water and slow-moving parts of streams; $1=$ species breeding in streams; 2 = species spawning outside the water; $3=$ species laying eggs in phytotelmata (e.g., bamboo holes, leaf axils of Pandanus and Ravenala). Species with specialised reproductive mode are more sensitive than others.

5. Activity type (AT): $0=$ species with aquatic habits; $1=$ species with nocturnal fossorial habits; $2=$ species with nocturnal above-ground activity; 3 = species with diumal above-ground activity. Nocturnal and secretive species are likely less subject to predation and collecting. Diurnal taxa depend more closely on habitat stability (constancy of humidity and temperature), and are consequently more sensitive to its alteration.

6. Geographic distribution (GD): $0=$ species found in both West and East; $1=$ species found in more than two vegetational domains, but only in East or West; 2 = species found in two domains; 3 = species found in one domain only. Amphibians with a wide distribution occurring at both the climatic/vegetational regions of Madagascar are usually characterised by higher adaptability. Geographic and climatic subdivision here follow Humbert (1955), although some considerations about the extension of these domains and regions by Raxworthy \& Nussbaum (1996a, 1997) were taken into consideration.

7. Altitudinal distribution (AD): $0=$ high altitude species $(>1200$ $\mathrm{m}) ; 1=$ mid-altitude species $(700-1200 \mathrm{~m}) ; 2=\mathrm{low} / \mathrm{mid}$-altitude species $(0-1200 \mathrm{~m}) ; 3=$ low altitude species $(<700 \mathrm{~m})$. Since human disturbance is usually more intense at low altitudes (where most towns and villages are located and deforestation is more intense), the occurrence of species at high altitudes represents per $s e$ an advantage in terms of survivorship and permanence of forested areas.

8. Number of findings (NF): $0=$ species with 11 and more findings; $1=6-10$ findings; $2=2-5$ findings; $3=1$ finding. Species with a large number of findings are more common (or easy to be found) and as a consequence less threatened than localized species. This parameter must anyway be taken into consideration together with the following one (EO).

9. Extent of occurrence (EO): $0=$ species with $\mathrm{EO}$ estimated to be $>20000 \mathrm{~km}^{2} ; 1=$ EO $5000-20000 \mathrm{~km}^{2} ; 2=$ EO $100-5000 \mathrm{~km}^{2} ; 3$ $=\mathrm{EO}<100 \mathrm{~km}^{2}$. The extent of occurrence is established according to Baillie \& Groobridge (1996) and IUCN (2001), and indicates the surface delineated by the known findings. Species with a wide extent of occurrence have a vast distribution, and are potentially less threatened. 
TABLE III - Scores for the variables affecting survival of the Malagasy anuran fauna sorted in terms of conservation priorities and ecological sensitivity.

OCU

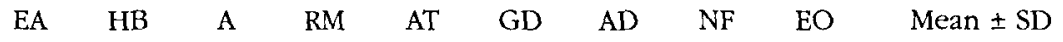

1 Mantella aurantiaca group

2 Mantella betsileo group (partim 2)

3 Mantella bernbardi group

4 Mantella laevigata group

5 Anodontbyla

6 Mantella cowani group

7 Mantella madagascariensis group

8 Blommersia (partim 2)

9 Chonomantis

10 Aglyptodactylus group 2

11 Madecassophryne-PletbodontobylaRbombopbryne

12 Stumpffia

13 Platypelis-Copbyla

14 Boophis tephraeomystax group (partim 2)

15 Pandanusicola

16 Mantidactylus boulengeri group

17 Spinomantis

18 Laurentomantis

19 Blommersia (partim 1)

20 Mantidactylus granulatus group

21 Mantidactylus asper group

22 Scapbiophryne group 2

23 Mantidactylus pseudoasper group

24 Boophis majori group

25 Boopbis luteus group

26 Guibemantis

27 Mantidactylus (partim 2)

28 Boopbis goudoti group

29 Mantella betsileo group (partim 1)

30 Scaphiopbryne group 3

31 Boophis microtympanum group

32 Heterixalus group 5

33 Boophis tephraeomystax group (partim 1)

34 Boophis albilabris group (partim 2)

35 Dyscophus group 1

36 Ochtbomantis

37 Boophis rappiodes group

38 Heterixalus group 3

39 Aglyptodactylus group 1

41 Heterixalus luteostriatus group

42 Brygoomantis

43 Heterixalus group 1

44 Mantidactylus (partim 1)

45 Scaphiophryne group 1

46 Heterixalus group 4

47 Laliostoma labrosum

48 Dyscopbus group 2

49 Paradoxophyla palmata

50 Hylobatracbus

51 Ptychadena mascareniensis

Mean variable values (SD)
40 Boophis albilabris group (partim 1)

\begin{tabular}{|c|c|c|c|c|c|c|c|c|c|}
\hline 3.00 & 1.00 & 3.00 & 2.00 & 3.00 & 3.00 & 1.00 & 2.67 & 2.67 & $2.37 \pm 0.84$ \\
\hline 2.50 & 1.00 & 3.00 & 2.00 & 3.00 & 3.00 & 2.50 & 2.00 & 1.50 & $2.28 \pm 0.71$ \\
\hline 3.00 & 1.00 & 3.00 & 2.00 & 3.00 & 3.00 & 1.00 & 2.00 & 2.00 & $2.22 \pm 0.83$ \\
\hline 3.00 & 1.00 & 3.00 & 3.00 & 3.00 & 2.00 & 2.00 & 1.00 & 1.00 & $2.11 \pm 0.93$ \\
\hline 2.75 & 3.00 & 2.00 & 2.00 & 1.00 & 3.00 & 1.50 & 1.75 & 1.50 & $2.06 \pm 0.72$ \\
\hline 2.50 & 1.00 & 3.00 & 2.00 & 3.00 & 3.00 & 1.75 & 1.00 & 1.25 & $2.06 \pm 0.85$ \\
\hline 2.50 & 1.00 & 3.00 & 2.00 & 3.00 & 3.00 & 1.50 & 1.50 & 1.00 & $2.06 \pm 0.85$ \\
\hline 3.00 & 1.00 & 3.00 & 2.00 & 1.00 & 3.00 & 1.50 & 2.00 & 1.50 & $2.00 \pm 0.83$ \\
\hline 2.86 & 0.86 & 3.00 & 2.00 & 3.00 & 2.43 & 1.57 & 0.86 & 1.14 & $1.97 \pm 0.90$ \\
\hline 2.00 & 1.00 & 3.00 & 0.00 & 1.00 & 3.00 & 3.00 & 2.50 & 2.00 & $1.94 \pm 1.07$ \\
\hline 3.00 & 2.00 & 3.00 & 2.07 & 0.00 & 2.36 & 1.71 & 1.64 & 1.50 & $1.92 \pm 0.90$ \\
\hline 1.00 & 2.00 & 3.00 & 2.00 & 1.00 & 2.63 & 2.00 & 2.13 & 1.50 & $1.92 \pm 0.67$ \\
\hline 2.60 & 2.90 & 1.20 & 3.00 & 1.00 & 2.30 & 1.60 & 1.40 & 1.10 & $1.90 \pm 0.80$ \\
\hline 3.00 & 1.00 & 1.00 & 0.00 & 1.00 & 3.00 & 3.00 & 2.50 & 2.50 & $1.89 \pm 1.14$ \\
\hline 2.80 & 3.00 & 2.00 & 3.00 & 1.00 & 2.20 & 2.00 & 0.80 & 0.20 & $1.89 \pm 1.02$ \\
\hline 3.00 & 1.36 & 0.91 & 2.00 & 1.00 & 2.73 & 2.27 & 1.73 & 1.45 & $1.83 \pm 0.73$ \\
\hline 3.00 & 0.83 & 2.17 & 2.00 & 1.00 & 2.33 & 2.33 & 1.67 & 1.17 & $1.83 \pm 0.72$ \\
\hline 3.00 & 1.00 & 1.00 & 2.00 & 1.00 & 2.25 & 2.25 & 1.75 & 1.75 & $1.78 \pm 0.69$ \\
\hline 2.00 & 1.00 & 2.43 & 2.00 & 1.00 & 2.57 & 1.86 & 1.43 & 1.29 & $1.73 \pm 0.58$ \\
\hline 2.50 & 1.00 & 1.00 & 2.00 & 1.00 & 2.63 & 1.88 & 1.88 & 1.63 & $1.72 \pm 0.63$ \\
\hline 2.14 & 2.00 & 1.00 & 2.00 & 1.00 & 2.29 & 2.14 & 1.57 & 1.29 & $1.71 \pm 0.51$ \\
\hline 2.80 & 1.00 & 3.00 & 0.00 & 0.00 & 3.00 & 1.80 & 2.00 & 1.60 & $1.69 \pm 1.17$ \\
\hline 2.50 & 1.00 & 1.00 & 2.00 & 1.00 & 2.50 & 1.50 & 1.50 & 2.00 & $1.67 \pm 0.61$ \\
\hline 2.00 & 1.00 & 1.11 & 1.00 & 1.00 & 2.78 & 1.78 & 2.00 & 1.89 & $1.62 \pm 0.63$ \\
\hline 1.73 & 1.00 & 2.00 & 1.00 & 1.00 & 2.45 & 1.64 & 1.82 & 1.36 & $1.56 \pm 0.51$ \\
\hline 1.80 & 2.00 & 2.00 & 2.00 & 1.00 & 2.20 & 1.40 & 1.00 & 0.20 & $1.51 \pm 0.66$ \\
\hline 3.00 & 0.00 & 0.00 & 2.00 & 0.00 & 3.00 & 1.50 & 1.50 & 2.50 & $1.50 \pm 1.25$ \\
\hline 2.44 & 1.00 & 1.89 & 1.00 & 1.00 & 2.00 & 1.56 & 1.44 & 1.00 & $1.48 \pm 0.53$ \\
\hline 2.00 & 1.00 & 3.00 & 2.00 & 3.00 & 0.00 & 2.00 & 0.00 & 0.00 & $1.44 \pm 1.24$ \\
\hline 2.50 & 1.00 & 3.00 & 0.00 & 0.00 & 3.00 & 0.00 & 2.00 & 1.50 & $1.44 \pm 1.26$ \\
\hline 3.00 & 0.00 & 1.00 & 1.00 & 1.00 & 3.00 & 0.00 & 1.67 & 2.00 & $1.41 \pm 1.12$ \\
\hline 0.00 & 1.00 & 1.00 & 0.00 & 1.00 & 3.00 & 2.67 & 1.67 & 2.33 & $1.41 \pm 1.09$ \\
\hline 2.00 & 1.00 & 1.00 & 0.00 & 1.00 & 1.67 & 2.67 & 1.67 & 1.67 & $1.41 \pm 0.76$ \\
\hline 2.00 & 1.00 & 2.00 & 1.00 & 1.00 & 1.00 & 2.00 & 2.00 & 0.00 & $1.33 \pm 0.71$ \\
\hline 0.00 & 0.00 & 3.00 & 0.00 & 0.00 & 3.00 & 3.00 & 2.00 & 0.50 & $1.28 \pm 1.44$ \\
\hline 2.75 & 0.00 & 0.00 & 2.00 & 0.75 & 2.50 & 2.25 & 0.75 & 0.50 & $1.28 \pm 1.09$ \\
\hline 1.00 & 1.00 & 1.00 & 1.00 & 1.00 & 2.00 & 2.00 & 1.50 & 0.25 & $1.19 \pm 0.56$ \\
\hline 0.00 & 1.00 & 1.00 & 0.00 & 1.00 & 2.33 & 2.33 & 1.67 & 1.33 & $1.18 \pm 0.85$ \\
\hline 2.00 & 1.00 & 3.00 & 0.00 & 1.00 & 1.00 & 2.00 & 0.00 & 0.00 & $1.11 \pm 1.05$ \\
\hline 2.00 & 1.00 & 2.00 & 1.00 & 1.00 & 1.00 & 2.00 & 0.00 & 0.00 & $1.11 \pm 0.78$ \\
\hline 0.00 & 1.00 & 1.00 & 0.00 & 1.00 & 3.00 & 3.00 & 1.00 & 0.00 & $1.11 \pm 1.17$ \\
\hline 2.11 & 0.00 & 0.00 & 2.00 & 0.00 & 2.56 & 1.11 & 0.89 & 1.11 & $1.09 \pm 0.98$ \\
\hline 0.00 & 1.00 & 1.00 & 0.00 & 1.00 & 2.33 & 1.17 & 1.00 & 1.00 & $0.94 \pm 0.69$ \\
\hline 2.00 & 0.00 & 0.00 & 2.00 & 0.00 & 2.00 & 2.50 & 0.00 & 0.00 & $0.94 \pm 1.13$ \\
\hline 1.00 & 1.00 & 3.00 & 0.00 & 0.00 & 1.00 & 2.50 & 0.00 & 0.00 & $0.94 \pm 1.13$ \\
\hline 0.00 & 1.00 & 1.00 & 0.00 & 1.00 & 1.00 & 2.00 & 2.00 & 0.00 & $0.89 \pm 0.78$ \\
\hline 0.00 & 1.00 & 3.00 & 0.00 & 0.00 & 1.00 & 3.00 & 0.00 & 0.00 & $0.89 \pm 1.27$ \\
\hline 1.00 & 0.00 & 3.00 & 0.00 & 0.00 & 0.00 & 3.00 & 0.00 & 0.00 & $0.78 \pm 1.30$ \\
\hline 2.00 & 0.00 & 0.00 & 0.00 & 0.00 & 2.00 & 2.00 & 1.00 & 0.00 & $0.78 \pm 0.97$ \\
\hline 1.00 & 0.00 & 0.00 & 2.00 & 0.00 & 1.00 & 2.00 & 0.00 & 0.00 & $0.67 \pm 0.87$ \\
\hline 0.00 & 0.00 & 0.00 & 0.00 & 0.00 & 0.00 & 2.00 & 0.00 & 0.00 & $0.22 \pm 0.67$ \\
\hline 1.95 & $\begin{array}{c}1.00 \\
(0.72)\end{array}$ & $\begin{array}{c}1.80 \\
(1.10)\end{array}$ & $\begin{array}{c}1.26 \\
(100)\end{array}$ & $\begin{array}{c}1.05 \\
(0.95)\end{array}$ & $\begin{array}{c}2.21 \\
(0.86)\end{array}$ & $\begin{array}{c}1.91 \\
(064)\end{array}$ & $\begin{array}{c}1.32 \\
(075)\end{array}$ & $\begin{array}{c}1.02 \\
(070)\end{array}$ & \\
\hline
\end{tabular}

Abbreviations: EA, environmental adaptability; HB, habitat breadth; A, arboreality; RM, reproductive mode; AT, activity; GD, geographic distribution; $\mathrm{AD}$, altitudinal distribution; NF, number of findings; $\mathrm{EO}$, extent of occurrence. 


\section{Statistical procedures}

Variables were assigned for each species; then the mean value was calculated within each OCU (Table III). The same was done at a higher taxonomic level, estimating the mean values for the microhylid subfamilies (Dyscophinae, Scaphiophryninae, and Cophylinae), mantellid subfamilies (Boophinae, Laliostominae, and Mantellinae), Hyperoliidae, and Ranidae. Mean scores from independent variables were used to estimate threat levels. Variables 1-7 are derived from ecology, and provide indications on the general capacity to adapt to habitat alterations. Variables 8-9 are related to the distribution and dispersion of findings: they reflect the biogeographic history of each species and the level of knowledge derived from survey works. Scores $(S) \pm S D$ were obtained for characterising each variable.

According to Andreone \& Luiselli (2000) scores 0-1 are associated with least or moderate risk, and scores $2-3$ with high or extremely high risk: (a) a mean score $<1.0$ indicates a species with no (or little) risk of decline, (b) a mean score $1.0<\mathrm{S}<1.6$ indicates a rather vulnerable species, and (c) a mean score $>1.6$ indicates a species potentially exposed to decline or even extinction.

The univariate method of obtaining a single mean ranking value was applied to all the variables. Cluster analysis (UPGMA, standardized to 100\%) and principal component analysis (PCA) were used to classify the OCUs in terms of relative ecological similarity. In this case, categories 1-7 only were used. Standard VARIMAX rotation of the data was applied to the PCA model to minimize the variable numbers with high coefficients on a given factor, and to maximize the correlation levels (Focardi, 1993). Rank data matrix was arcsin-transformed prior to applying any analysis, as PCA is devised to analyse continuous data-sets only. Throughout the text we use the terms "vulnerable" and "threatened" only to explain the conservation status of the discussed taxa or OCUs; they do not necessarily correspond to homonymous IUCN categories (IUCN, 2001).

\section{RESULTS}

\section{Scores for individual variables in the various groups}

Operational conservation unit's values ranged from 0.22 (Ptychadena mascareniensis) to 2.37 (Mantella aurantiaca group). Nine OCUs ( $17.6 \%$ of the total) had values lower than 1.00 , and are here considered as non-threatened. They are: Heterixalus group 1, Heterixalus group 4, Dyscopbus group 2, Paradoxophyla palmata, Scaphiophryne group 1, Ptychadena mascareniensis, Laliostoma labrosum, Brygoomantis, Hylobatrachus, Mantidactylus (partim 1). Five are distributed only (Scaphiophryne group 1, L. labrosum, Dyscophus insularis), or also (Heterixalus group 1 and P. mascareniensis) in western areas. Mantidactylus lugubris, M. grandidieri and $M$. guttulatus, included in this category, are aquatic frogs, which although originally living in mature rainforest habitats, can be found in degraded areas too, at least where a gallery forest along streams is present (Andreone, 1994, 1999, in press a; Andreone \& Randrianirina, 2000; Andreone et al., 2000). Eighteen OCUs (35.3\%) scored 1.00-1.60, and are viewed as quite sensitive, although still rather adaptable. They include riverine and/or arboreal groups, such as the Boophis rappiodes, B. albilabris, B. luteus, B. microtympanum, Mantidactylus pseudoasper, Ochtbomantis, and Mantella betsileo groups. They have a life style that allows them to adapt to ecotonal environments (Andreone, 1994).
Twenty-four OCUs (47.1\%) scored $>1.60$, and are considered as very sensible to habitat alterations. Typically, they are specialised rainforest species, represented by two species groups. A first one (composed, among others, by Chonomantis, Pandanusicola, Mantidactylus boulengeri group, Spinomantis, Laurentomantis, Aglyptodactylus group 2, and cophylines) is usually confined to forest habitats: these species suffer from habitat alterations. The second group, which also shows the highest ranked OCUs, includes most of the Mantella OCUs, which have a narrow distribution, diurnal activity and are subject to trade. Most of mantellas are confined to rainforests, although some of them (e.g., M. expectata, $M$. betsileo, $M$. viridis) occur in dry western areas (Vences et al., 1999; Staniszewski, 2001)

Values ranked from 1.00 (HB, habitat breadth), and 1.02 (EO, extent of occurrence) to 2.21 (GD, geographic distribution). Four (EA, A, GD, NF) out of nine variables had values $>1.5$, which indicates that these are the most important for these vertebrates. The low value for $\mathrm{HB}$ (habitat breadth, 1.00) indicates that most of Mantidactylus and Boophis species (which constitute the majority of Malagasy amphibians) usually live not very far from marshes, ponds, or forest streams, and may survive only in their proximity. A few species (mainly cophyline microhylids and some direct Mantidactylus developers) reproduce far from the water; they therefore need a sufficiently stable forest environment, with a certain degree of leaf litter humidity or presence of a conspicuous epiphytic flora. The rather high mean value of EA (environmental adaptability, 1.95) is due to the fact that great part of the amphibians is rainforest specialist. High scores for both AD (altitudinal distribution, 1.91) and GD (geographic distribution, 2.21) indicate that most species are ecological specialists, restricted to limited habitats and territories.

\section{Chuster and principal component analyses}

The cluster analysis arranged the 51 OCUs into some defined groups (Fig. 1). A major division occurred at a linkage distance comprised between 80 and 100\%. Two groups are evident: a first one (here named $\mathrm{A}$ ), is represented by 13 OCUs, and the second (B), by the remaining ones. Group A is composed by the most adaptable amphibians. Among these Ptychadena mascareniensis (A1) is known to occur in a wide habitat range, from open areas within or around rainforests, to ricefield paddies of the high plateau, and to the western marshes and ephemeral ponds. A clearly identifiable cluster is represented by five Heterixalus OCUs: they all show uniform natural history traits, include ecotonal species, and only rarely may be found in forest habitats. The rest of the group is composed by some microhylids, two Boophis and one Aglyptodactylus. Scaphiophryne brevis, $S$. calcarata and Laliostoma labrosum are fossorial species which have a western-oriented distribution, and are "explosive breeders", that reproduce during the 
100

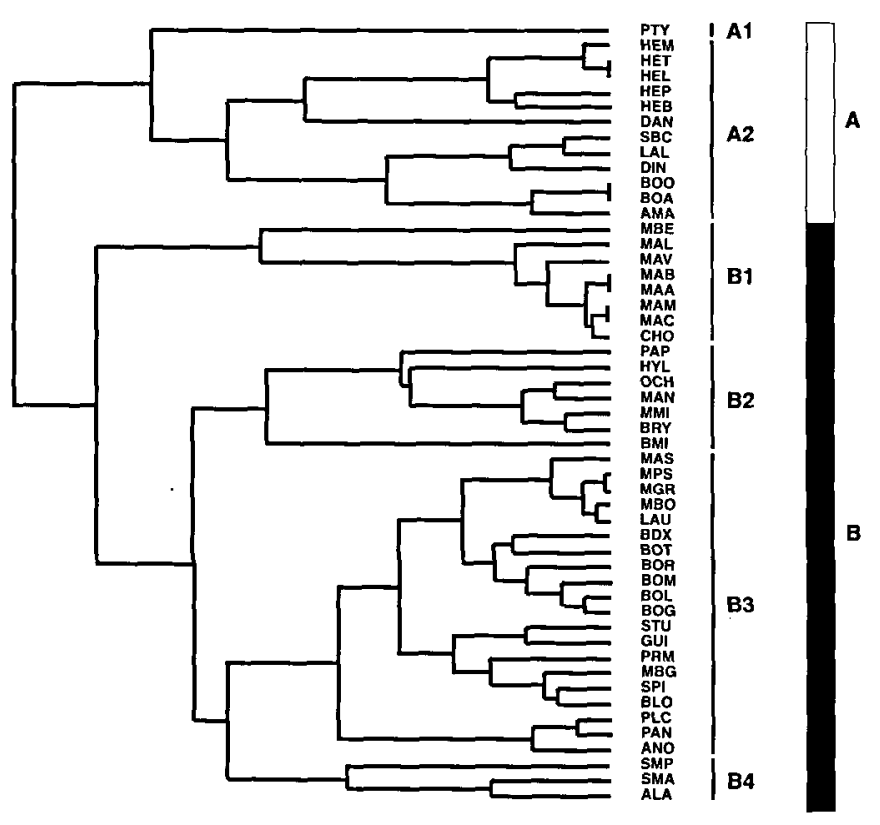

Fig. 1 - UPGMA tree diagram clustering the operational conservation units (OCUs) of Malagasy amphibians on the basis of the scores presented in Table III. Abbreviations as in Tables I, II.

short and intense rainy season. Boophis albilabris and $B$. occidentalis show a peculiar breeding aggregation which is rare for the forest species of this genus (Andreone et al., 2002). Dyscophus antongili and D. guineti live in the humid rainforest belt, where they prefer the coastal temporary ponds for breeding (or, secondarily, the ricefields). All these OCUs (A2) in general are not so threatened by habitat alteration, and are able to colonise newly constituted ponds in small forest patches. Indeed, all these species prefer open areas, or, in the case of the Boophis, they live in dry-deciduous or transitional deciduous-Sambirano forests (Andreone et al., 2001).

The second cluster (Group B) mainly identifies rainforest OCUs. Only a few of these species live in the western areas. This is the case of some species of the Brygoomantis subgenus, Mantella betsileo, $M$. expectata, and Mantella sp. 1. Within this cluster, we identify some other groups which share common ecological traits, e.g., a group composed by seven Mantella OCUs (plus Chonomantis) (B1). The assemblage composed by Paradoxophyla palmata, Hylobatrachus, Ocbtomantis, Mantidactylus (partim 1), Mantidactylus (partim 2), and Brygoomantis (B2), is, among the rainforest representatives, the one with the most adaptable species. Then, the third group (B3) includes most of the Mantidactylus, the remaining Boophis, and the microhylids (mainly cophylines) typical of intact rainforest. The last cluster (B4) includes Aglyptodactylus group 2, and two Scaphiophryne. All these groups include species which are particularly specialised (e.g., the species of the subgenera Pandanusicola, Spinomantis, and Laurentomantis, and the cophyline microhylids which breed in phytotelmata).
The general repartition and sensibility in terms of ecological patterns is also observed in the subsequent PCA carried out on the suprageneric taxa. Application of a standardised VARIMAX rotation on a PCA model gave a $\log _{10}$ determination correlation matrix $=-3.1246$, and eigenvalues of 3.838 and 1.773 and 1.542 (see factor scores in Table IV).

In the score plot by factors (Fig. 2), the main variables ordering the various families along Factor 2 were environmental adaptability (EA) and geographic distribution (GD) (28.9\% of the total variance explained). Factor 3 comprised arboreality (A), geographical distribution (GD), and $\mathrm{AD}$ ( $22.4 \%$ of the total variance accounted for).

These values stress the fact that Cophylinae are among the most sensitive of the Malagasy rainforest amphibians, followed by Mantellinae and Boophinae. The group composed by Scaphiophryninae and Hyperoliidae appear less sensitive, together with Dyscophinae. The general repartition and ecological sensitivity of these groups is clearly dependent upon the peculiar reproductive traits of some of them (e.g., cophylines, mantellines) versus a general adaptive capacity of the others. The species of the genus Boophis are ecologically intermediate between the most and the least sensitive groups.

\section{DISCUSSION}

\section{Ecological sensitivity and conservation}

The results shown in this paper help in drawing up a general conservation scenario for the Malagasy batrachofauna. The two kinds of analysis provided a general arrangement that might be interpreted from both the ecological and conservation points of view. As already stressed, the groups were subject to different threats. Indeed, much work remains to be done, even to know the distribution of most species better, as well as their natural history traits. Furthermore, the taxonomy of the Malagasy amphibians is currently in progress, and many

TABLE IV - Scores of first three factors on cases (variables), after VARIMAX normalized rotation, in the sets of PCA performed on Malagasy anuran families and subfamilies.

Factor Scores

Factor 1 Factor 2 Factor 3

$\begin{array}{lrrr}\text { EA } & 0.04 & 1.17 & -0.08 \\ \text { HB } & 0.07 & 0.63 & -0.05 \\ \text { A } & -0.03 & -0.48 & 0.79 \\ \text { RM } & -0.02 & -0.27 & 0.01 \\ \text { AT } & 0.01 & 0.04 & 0.25 \\ \text { GD } & 0.15 & 1.25 & 0.42 \\ \text { AD } & 0.11 & -0.50 & 1.77 \\ \text { Percentage of explained variance } & 43.00 & 28.90 & 22.40\end{array}$

Abbreviations as in Table III. 


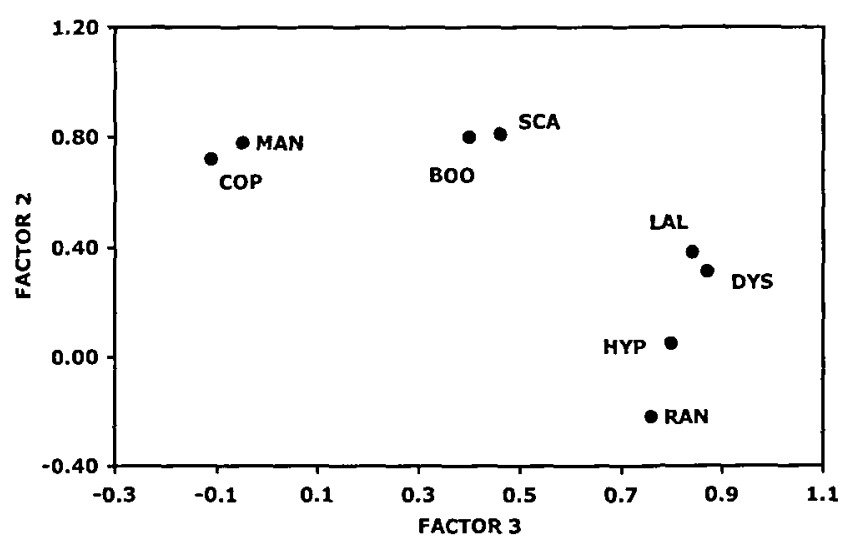

Fig. 2 - Two-dimension plot of scores for families and subfamilies of Malagasy amphibians by factors using a standardised VARIMAX rotated model PCA. Abbreviations as in Tables I, II.

more species will be certainly discovered within a few years. This means that conservation actions must necessarily take into considerations the knowledge of taxa, and that more efforts should be made to protect locally endemic amphibians and especially their habitats. Bearing this in mind, we are anyway confident that the results provided here afford a good material upon which discussing the status of Malagasy amphibians.

The univariate and multivariate analyses gave comparable results: the differences consisted in the fact that the simple ranking emphasised the conservation aspects (also including the parameters of geographic distribution and extent of occurrence), while the two multivariate analyses grouped the amphibians mainly on the basis of their ecological similarities, and, consequently, sensitivity.

As a common result it is evident that some amphibians, such as mantellines and cophylines, are particularly related to rainforest habitats, exhibiting peculiar specialisations mainly related to their breeding biology and to the ecosystem's stability (Andreone, 1994; Vallan, 2000b). Only a few mantellines (e.g., Mantidactylus ulcerosus, $M$. corvus, Mantella betsileo, M. expectata) were able to colonise the western dry areas, while no cophyline microhylid is known from the West (excluding the humid and rainforest-like Sambirano, in the Northwest). A similar trend is observed in boophines, which are represented in western Madagascar by a few species of the Boophis tephraeomystax group (B. doulioti, B. xerophilus) and by $B$. occidentalis (Andreone et al., 2002). Cophylines are among the most sensitive frogs, since they utilise phytotelmata for reproduction (e.g., Platypelis, Cophyla spp.), or build nests in the ground (e.g., Stumpffia, Pletbodontobyla, and Rbombopbryne). For this behavioural trait they usually need a rather stable environment, although several species of the genus Stumpffia can also live around villages or in very small forest patches.

Other taxa, like Hyperoliidae and Ranidae, are rather generalist frogs and with a "typical" anuran reproduction, use still water bodies, and lay a large number of eggs. The genus Heterixalus is primarily a savannah species, and does not penetrate real pristine rainforests. The ranid Ptychadena mascareniensis, which is widely distributed in Madagascar (but usually not in the primary rainforest), is a non-endemic species, likely introduced in historical times to Madagascar by the first inhabitants; it shows good adaptive capacity.

It can therefore be hypothesised that the degradation and fragmentation of forest habitats (in particular of lowland and mid-altitude rainforests) will cause the dramatic reduction, or even extinction (at local level), of most mantelline and cophyline faunae. As witnessed by Vallan (2000b), fragmentation of the forests is accompanied by a substantial reduction of number and "type" of species, and in general the species which may survive in the small patches are those which may benefit from the presence of streams. Apparently less endangered, at least from habitat disturbance, are those taxa, like hyperoliids, laliostomines, and some boophines, which are pond-breeders and live around temporary water bodies and marshes. This aspect was already evidenced by other studies (Andreone, 1994, 1999), where it turned out that altered forests are characterised by a comparatively low number of species belonging to the genera Mantidactylus and Mantella, as well as cophyline microhylids.

\section{Influence of the pet trade}

A further aspect that must be taken into consideration for conservation is the effect of capture for the pet trade. Almost all the mantellas are actively searched for and traded: for this reason the whole genus was recently included in CITES II. Some species (e.g., Mantella betsileo, and $M$. baroni), are still widely distributed, and locally abundant, while others (e.g., M. aurantiaca, $M$. cowani, $M$. bernhardi, $M$. expectata, and $M$. viridis) have a very narrow distribution. Analysis of the capture effect on Malagasy herpetofauna is still lacking and often subject of fierce dispute: although it is not yet possible to provide sound data on the influence of capture on natural populations, it is likely that when ecological requirements and sensitivity to habitat alteration go together with conspicuous capture for commerce, the species in question become concurrently more endangered. The capture of thousands of individuals per year of the golden frog $M$. aurantiaca indeed constitutes a potential threat for the species survival (Zimmermann, 1996; Rakotomavo, 2001; Staniszewski, 2001): just to give an idea, the annual exportation number of $M$. aurantiaca in 1996 was of about 17000 individuals (T. Rahagalala \& H. Randrianasolo, 2000, unpubl. rep. to WCS). Another species, $M$. cowani, is also peculiar in terms of distribution, since it is restricted to the central plateau, an area which is currently almost completely spoiled (Raxworthy \& Nussbaum, 1996b). According to Vences et al. (1999) this species is known from a few forested regions SE of Ambatolampy, and near Antoetra, although museum vouchers witness for its presence at some other localities. At Antoetra, M. cowani was still 
apparently abundant until several years ago, and captured in large numbers (Rakotomavo, 2001). Similarly, the recently described $M$. bernbardi is apparently known only from a small forest close to Tolongoina in southern-eastern Madagascar (Raxworthy \& Nussbaum, 2000), although unpublished information by J. E. Cadle suggests a wider species repartition. The potential demand for trade of these species is still high, and may generate high "pressures" on the populations and on the habitats when collecting activity is not controlled.

A different case related to trade and commerce is that of the "tomato frog", Dyscophus antongili. Surprisingly, except for a few notes on captive specimens (e.g., Pintak, 1987) little is known about its distribution, and therefore any conservation assessment is difficult. This is the only Malagasy amphibian currently included in CITES I. Its inclusion was due to the high numbers of exported specimens and the apparent vulnerability of the species. Anyhow, its distribution, although likely more extended than formerly believed, is not yet well known. It seems probable that, although not so threatened by deforestation (living in open areas and ricefields), it might suffer due to the human activities (Glaw \& Vences, 1994). Dyscopbus antongili is among the few Malagasy amphibians, which are more or less regularly bred in captivity, and this constitutes an advantage with respect to other species. Instead, attention should be paid to the situation regarding the related and phenotypically similar $D$. guineti, which is more subject to capture as a consequence of the inclusion of $D$. antongili in CITES I. The considerably low ranking for both these species, as reported in Table III, indicates that both are ecologically adaptable and can recover whenever the original habitat conditions are restored and capture regimented.

Last but not least, it is also worth quoting the situation regarding a recently described species, Scaphiophryne gottlebei. According to current information its distribution is limited to a few dry areas close to Isalo National Park, SW Madagascar. Due to its peculiar and attractive colouration, it is in high demand for the pet-trade, but, as for the other species, virtually nothing is known about its biology. Beside its ecological characteristics (it is likely a fossorial frog), it is also extremely interesting from the evolutive point of view, being a tetraploid species (Vences et al., 2002c).

\section{Recommendations for conservation}

The conservation of Madagascan fauna and flora cannot be achieved without a series of political actions, and the consensus of local populations. Such actions include the active protection of Madagascar's original habitats, control of exportation and restoration projects. In this direction many NGOs (e.g., WWF, Wildlife Conservation Society, and Conservation International) are acting towards the management of several protected areas in collaboration with Malagasy authorities. Furthermore, many other initiatives are on the way, and there is the hope that they will obtain some sound results (ANGAP, 2001).

In terms of conservation of the autochthonous batrachofauna it is our opinion that it should include a mix of habitat protection, pet-trade regulation, and sustainable use of resources. This was outlined by several Authors, among whom Jenkins \& Rakotomanampison (1994) and Jenkins (2000). As for other taxa, it is crucial that conservation actions be accompanied by campaigns aimed at increasing the public's awareness and education, showing them the importance of amphibians within the nature network. This might be done through public-oriented initiatives (e.g., publication of popular leaflets, exhibitions, conferences), and the training of university students and reserve guides to work in protected areas. Apart from these general indications, we suggest that for conservation purposes particular attention should be addressed to the following points:

1. Urgent decisions regarding the commerce of most of the Mantella species. In terms of categorisation they gained the highest ranks and occupied a well-defined place in the cluster analysis. Furthermore, they represent the majority of Malagasy amphibians exported for commercial purposes. We recommend defining a sustainable exportable quota (or even temporarily banning the commerce) of the most endangered mantellas, such as $M$. cowani, M. bernbardi, M. expectata, and $M$. aurantiaca.

2. Few data are currently available for three of the apparently most endangered species: $M$. cowani, $D$. antongili, and $S$. gottlebei. Surveys must be carried out to define more clearly their distribution and basic biological requirements.

3. The ongoing taxonomic investigation should be reinforced: this will allow us to distinguish closely related and "hidden" sibling species with simple and powerful tools, such as DNA and karyological analyses.

\section{REFERENCES}

Andreone F., 1993 - Kommentierte Liste von Amphibienfunden auf Madagaskar. Salamandra, 29: 67-78.

Andreone F., 1994 - The amphibians of Ranomafana rain forest, Madagascar - preliminary community analysis and conservation considerations. Oryx, 28: 207-214.

Andreone F., 1996 - Another green treefrog, Boopbis anjanabaribeensis n.sp. (Ranidae: Rhacophorinae), from northeastern Madagascar. Aqua, J. Ichthyol. Aquat. Biol., 2: 25-32.

Andreone F., 1999 - Madagascar amphibians. In: S. Yamagishi (ed.), The animals of Madagascar - its wonderful adaptive radiation [in Japanese]. Shokabo Publishing, Tokyo, pp. 213-261

Andreone F., in press a - The amphibians and reptiles of Madagascar: species diversity and conservation perspectives. In: $\mathrm{R}$. Polymeni (ed.), Proceedings of the $1^{\text {st }}$ new international congress of zoology, Athens.

Andreone $\mathrm{F}$, in press $\mathrm{b}$ - The genus Mantidactylus. In: S. M. Goodman \& J. P. Benstead (eds), The natural history of Madagascar, Chicago University Press, Chicago.

Andreone F., Aprea G., Vences M., Odierna G., in press - A new Mantidactylus frog from the rainforests of north-eastern Madagascar, and its karyological relationships. Amphibia-Reptilia.

Andreone F., Glaw F., Vences M., Vallan D., 1998 - A new Manti- 
dactylus (Ranidae: Mantellinae) from south-eastern Madagascar, with a review of Mantidactylus peraccae (Ranidae: Mantellinae). Herpetol. J., 8: 149-159.

Andreone F., Luiselli L., 2000 - The Italian batrachofauna and its conservation status: a statistical assessment. Biol. Conserv., 96: 197-208.

Andreone F., Nincheri R., Piazza R., 1995 - Un nouveau Boophis vert (Ranidae: Rhacophorinae) des forêts pluviales du S. Madagascar. Rev. Fr. Aquariol., 21: 121-127.

Andreone F., Randrianirina J. E., 2000 - Biodiversity, rainforests and herpetological communities in Madagascar: what about differences in amphibians and reptiles? In: W. R. Lourenço \& S. M. Goodman (eds), Diversity and endemism in Madagascar. Mém. Soc. Biogéographie, Paris, pp. 249-260.

Andreone F., Randrianirina J. E., Jenkins P. D., Aprea G., 2000 Species diversity of Amphibia, Reptilia and Lypotyphla (Mammalia) at Ambolokopatrika, a rainforest between AnjanaharibeSud and Marojejy massifs, NE Madagascar. Biodivers. Conserv., 9: $1587-1622$.

Andreone F., Vences M., Guarino F. M., Glaw F., Randrianirina J. E., 2002 - Natural history and larval morphology of Boophis occidentalis (Anura: Mantellidae: Boophinae) provide new insights into the phylogeny and adaptive radiation of endemic Malagasy frogs. J. Zool. (Lond.), 257: 425-438.

Andreone F., Vences M., Randrianirina J. E., 2001 - Patterns of amphibian and reptile diversity at Berara Forest (Sahamalaza Peninsula), NW Madagascar. Ital. J. Zool., 68: 235-241.

ANGAP, 2001 - Plan de gestion du réseau national des aires protégées de Madagascar. ANGAP and Ministère de l'Environnement, Antananarivo.

Baillie B., Groombridge B., 1996 - The 1996 IUCN red list of threatened species. Gland, IUCN and Conservation International, Cambridge and Washington.

Behra O., Raxworthy C. J., 1991 - Exportation des amphibiens de Madagascar. Interet, danger et perspectives d'avenir. Circalytes, 5: $45-49$.

Benstead J. P., Stiassny M. L. J., Loiselle P. V., Riseng K. J., Raminosoa N., 2000 - River conservation in Madagascar. In: P. J. Boon, B. R. Davies \& G. E. Petts (eds), Global perspectives of river conservation: science, policy and practice. John Wiley and Sons, Chichester, pp. 205-231.

Blanc Ch. P., Blanc F., Roualt J., 1983 - The interrelationships of Malagasy iguanids. J. Herpetol., 17: 129-136.

Blaustein A. R., Wake D. B., 1990 - Declining amphibian population: a global phenomenon? Trends Ecol. Evol., 5: 203-204.

Blommers-Schlösser R. M. A., 1993 - Systematic relationships of the Mantellinae Laurent 1946 (Anura Ranoidea). Ethol. Ecol. Evol., 5: 199-218.

Blommers-Schlösser R. M. A., Blanc C. P., 1991 - Amphibiens (première partie). Faune de Madagascar, 75: 1-380.

Cadle J. E., 1995 - A new species of Boophis (Anura: Rhacophoridae) with unusual skin glands from Madagascar, and a discussion of variation and sexual dimorphism in Boophis albilabris (Boulenger). Zool. J. Linn. Soc., 115: 313-345.

Daly J. W., 1984 - Occurrence of skin alkaloids in non-dendrobatid frogs from Brazil (Bufoonidae), Australia (Myobatrachidae) and Madagascar (Mantellinae). Toxicon, 22: 905-919.

Duellman W. E., Trueb L., 1986 - Biology of amphibians. McGraw-Hill, New York.

Focardi S., 1993. Metodi multivariati. In: J. Fowler \& L. Cohen (eds), Statistica per ornitologi e naturalisti. Franco Muzzio and Co., Padova, pp. 193-213.

Ganzhorn J., Lowry P. P. II, Schatz G. E., Sommer S., 2001 - The biodiversity of Madagascar: one of the world's hottest hotspots on its way out. Oryx, 35: 346-348.

Glaw F., Vences M., 1994 - A fieldguide to the amphibians and reptiles of Madagascar. Second edition, including freshwater fish and mammals. Vences und Glaw Verlag, Cologne.

Glaw F., Vences M., 1997a - Neue Ergebnisse zur Boophis goudotiGruppe aus Madagaskar: bioakustik, Fortpflanzungsstrategien und Beschreibung von Boophis rufioculis sp. nov. Salamandra, 32: $225-242$.
Glaw F., Vences M., 1997b - Neue Date über die Mantidactylus-Untergattung Spinomantis (Anura: Ranidae: Mantellinae) aus Madagaskar, mit Beschreibung einer neuen Art. Salamandra, 32: 243-258.

Glaw F., Vences M., 1997c - New species of the Boophis tephraeomystax group (Anura: Ranidae: Rhacophorinae) from arid western Madagascar. Copeia, 1997: 572-578.

Glaw F., Vences M., 1999 - Resurrection and redescription of Mantidactylus tricinctus from eastern Madagascar. J. Herpetol., 33: 639-647

Glaw F., Vences M., 2000 - Current counts of species diversity and endemism of Malagasy amphibians and reptiles. In: W. R. Lourenço \& S. M. Goodman (eds), Diversity and endemism in Madagascar. Mém. Soc. Biogéographie, Paris, pp. 243-248.

Glaw F., Vences M., 2001 - Two new sibling species of Mantidactylus cornutus from Madagascar. Spixiana, 24: 177-190.

Glaw F., Vences M., 2002 - A new sibling species of the anuran subgenus Blommersia from Madagascar (Amphibia: Mantellidae: Mantidactylus) and its molecular phylogenetic relationships. Herpetol. J., 12: 11-20.

Glaw F., Vences M., in press - A new species of Mantidactylus (Anura: Mantellinae) from Andasibe in central eastern Madagascar. Copeia.

Glaw F., Vences M., Andreone F., Vallan D., 2001 - Revision of the Boophis majori group (Amphibia: Ranidae: Rhacophorinae) from Madagascar, with description of five new species. J. Linn. Soc. Lond. Zool., 133: 495-529.

Glaw F., Vences M., Böhme W., 1998 - Systematic revision of the genus Aglyptodactylus Boulenger, 1919 (Amphibia: Ranidae), and analysis of its phylogenetic relationships to other Madagascan ranid genera (Tomopterna, Boophis, Mantidactylus, and Mantella). J. Zool. Syst. Evol. Res., 36: 17-37.

Glaw F., Vences M., Gossmann. V., 2000 - A new species of Mantidactylus from Madagascar, with a comparative survey of internal femoral gland structure in the genus (Amphibia: Ranidae: Mantellinae). J. Nat. Hist., 34: 1135-1154.

Hero J.-M., Gillespie G. R., 1997 - Epidemic disease and amphibian declines in Australia. Conserv. Biol., 11: 1-3.

Heyer W. R., Rand A. S., Goncalvez da Cruz C. A., Peixoto O. L., 1988 - Decimations, extinctions, and colonizations of frog populations in southeast Brazil and their evolutionary implications. Biotropica, 20: 230-235.

Humbert H., 1955 - Les territoires phytogéographiques de Madagascar. Leur cartographie. Ann. Biol., 31: 195-204.

IUCN, 2001 - IUCN Red List Categories: Version 3.1. Prepared by the IUCN Species Survival Commission. IUCN, Gland, Cambridge.

Jenkins R. W. G., 2000 - Commercial use and export of chamaeleonid and phelsumid lizards in Madagascar - an experiment in adaptive management. In: J. Berney (ed.), In search of innovative conservation initiatives. Journal of Sustainable Use (Report of the proceedings $2^{\text {nd }}$ symposium on sustainable use of wildlife resources), pp. 1-9 (unnumbered, web address: http://www.iwmc.org).

Jenkins M., Rakotomanampison A., 1994 - Export trade in Madagascar's plants and animals: consequences for species survival. Technical Report of Tropical Research and Development to USAID. Association for the Management of Protected Areas, Antananarivo.

Lemckert F., 1999 - Impacts of selective logging on frogs in a forest area of northern New South Wales. Biol. Conserv., 89: 321-328.

Myers N., Mittermeier R. A., Mittermeier C. G., da Fonseca G. A. B., Kent J., 2000 - Biodiversity hotspots for conservation priorities. Nature, 403: 853-858.

Odierna G., Vences M., Aprea G., Lötters S., Andreone S., 2001 Chromosome data for Malagasy poison frogs (Amphibia: Ranidae: Mantella) and their bearing on taxonomy and phylogeny. Zool. Sci., 18: 505-514.

Pintak T., 1987 - Zur Kenntnis des Tomatenfrosches Dyscophus antongili (Grandidier, 1877) (Anura: Microhylidae). Salamandra, 23: 106-121.

Pough F. H., Andrews R. M., Cadle J. E., Crump M. L., Savitzski A. H., Wells K. D., 1998 - Herpetology. Prentice Hall, New Jersey. 
Rakotomavo E., 2001 - Etude de la filière Mantella de Madagascar. Office National pour l'Environnement, Antananarivo.

Raxworthy C. J., Forstner M. R. J., Nussbaum R. A., 2002 Chameleon radiation by oceanic dispersal. Nature, 415: 784$-787$.

Raxworthy C. J., Nussbaum R. A., 1996a - Patterns of endemism for terrestrial vertebrates in eastern Madagascar. Biogéographie de Madagascar. In: W. R. Lourenço (ed.), Biogéographie de Madagascar. Orstom, Paris, pp. 369-383.

Raxworthy C. J., Nussbaum R. A., 1996b - Montane amphibian and reptile communities in Madagascar. Conserv. Biol., 10: 750-756.

Raxworthy C. J., Nussbaum R. A., 1997 - Biogeographic patterns of reptiles in eastern Madagascar. In: S. M. Goodman \& B. D. Patterson (eds), Natural change and human impact in Madagascar. Smithsonian Institution, Washington, pp. 124-141.

Raxworthy C. J., Nussbaum R. A., 2000 - Extinction and extinction vulnerability of amphibians and reptiles in Madagascar. Amph. Rept. Conserv., 2: 15-23.

Rödel M.-O., 2000 - Herpetofauna of West Africa. Vol. I. Amphibians of the West African savanna. Edition Chimaira, Frankfurt am Main.

Staniszewski M., 2001 - Mantellas. Edition Chimaira, Frankfurt am Main.

Tonge S., 1991 - Initial assessment of the conservation status of the amphibians of Madagascar. CBSG News, 2: 12.

Vallan D., 2000a - A new species of the genus Stumpffia (Amphibia: Anura: Microhylidae) from a small forest remnant of the central high plateau of Madagascar. Rev. Suisse Zool., 107: 835$-841$.

Vallan D., 2000b - Influence of forest fragmentation on amphibian diversity in the nature reserve of Ambohitantely, highland Madagascar. Biol. Conserv., 96: 31-43.

Vences M., Andreone F., Glaw F., Kosuch J., Meyer A., Schaefer C., Veith M., 2002a - Exploring the potential of life-history key innovation: brook breeding in the radiation of the Malagasy treefrog genus Boophis. Mol. Ecol., 11: 1453-1463.

Vences M., Andreone F., Glaw F., Mattioli F., in press a - New dwarf species of Mantidactylus from north-western Madagascar (Anura: Mantellidae). Copeia.

Vences M., Andreone F., Glaw F., Randrianirina J. E., 2002b - Molecular and bioacoustic divergence in Mantidactylus granulatus (Anura: Mantellidae): bearings for the biogeography of northern Madagascar. Afr. Zool.

Vences M., Aprea G., Capriglione T., Andreone F., Odierna G., $2002 \mathrm{c}$ - Ancient tetraploidy and slow molecular evolution in Scaphiopbryne: ecological correlates of speciation mode in
Malagasy relict amphibians. Chromosome Res., 10: 127-136.

Vences M., Glaw F., 2001a - When molecules claim for taxonomic changes: new proposals on the classification of Old World treefrogs. Spixiana, 24: 85-92.

Vences M., Glaw F., 2001b - Systematic review and molecular phylogenetic relationships of the direct developing Malagasy anurans of the Mantidactylus asper group (Amphibia: Mantellidae). Alytes, 19: 107-139.

Vences M., Glaw F., 2002 - Molecular phylogeography of Boophis tephraeomystax: a test case for east-west vicariance in Malagasy anurans (Amphibia, Anura, Mantellidae). Spixiana, 25: 79-84.

Vences M., Glaw F., in press - Revision of the subgenus Cbonomantis (Anura: Ranidae: Mantidactylus) from Madagascar, with description of two new species. J. Nat. Hist.

Vences M., Glaw F., Andreone F., Jesu R., Schimmenti G., 2002d Systematic revision of the enigmatic Malagasy broad-headed frogs (Laurentomantis Dubois, 1980), and their phylogenetic position within the endemic mantellid radiation of Madagascar. Contrib. Zool., 70: 191-212.

Vences M., Glaw F., Böhme W., 1999 - A review of the genus Mantella (Anura, Ranidae, Mantellinae): taxonomy, distribution and conservation of Malagasy poison frogs. Alytes, 17: 3-72.

Vences M., Glaw F., Jesu R., Schimmenti G., 2000b - A new species of Heterixalus (Amphibia: Hyperoliidae) from western Madagascar. Afr. Zool., 35: 269-276.

Vences M., Glaw F., Kosuch J., Böhme W., Veith M., 2001 - Phylogeny of South American and Malagasy boine snakes: molecular evidence for the validity of Sanzinia and Acrantophis and biogeographic implications. Copeia, 2001: 1151-1154.

Vences M., Glaw F., Kosuch J. Das I., Veith M., 2000a - Polyphyly of Tomopterna (Amphibia: Ranidae) based on sequences of the mitochondrial 16S and 12S rRNA gene, and ecological biogeography of Malagasy relict amphibian groups. In: W. R. Lourenço \& S. M. Goodman (eds), Diversity and endemism in Madagascar. Mém. Soc. Biogéographie, Paris, pp. 229-242.

Vences M., Raxworthy C. J., Nussbaum R. A., Glaw F., in press bA revision of the Scapbiophryne marmorata complex of marbled toads from Madagascar, including the description of a new species. Herpetol. J.

Young B. E., Lips K. R., Reaser J. K., Ibànez R., Salas A. W., Cedeño J. R., Coloma L. A., Ron S., de la Marca E., Meyer J. R., Muñoz A., Bolaños F., Chaves G., Romo D., 2001 - Population declines and priorities for Amphibian conservation in Latin America. Conserv. Biol., 15: 1213-1223.

Zimmermann H., 1996 - Der Schutz des tropischen Regenwaldes und ein kleines Fröschchen in Ost-Madagaskar. Stapfia, 47: 189-218 . 